decks. The most striking feature of measurements on bridges has been the low values for the strains measured in the girders, even with heavy traffic. Laboratory tests on scale-models have helped to explain this, particularly on the basis of composite action between the girders and the concrete and of the lateral distribution of load among the girders. Several possible new methods of design are being investigated, with the view of gaining all possible advantage from this structural interaction, which previously was ignored.

A working model was used in the exhibition to illustrate a series of tests that measured the dynamic effects of traffic. The impact factor (the ratio of the strain due to a load applied dynamically to that due to the same load applied statically) varied in most cases between $0 \cdot 8$ and $1 \cdot 3$, the commonest values being about unity. In the past, it has been usual to assume an impact factor of $\mathbf{1 . 5}$ or more for design purposes; but the tests show that such a value is unduly high and that a more economical design can be made on the safe basis of an impact factor of $\mathbf{1 . 2 5}$ or even less.

The work on bridges demonstrates in parvo nearly all the principles characterizing the present-day approach to the problems of designing structures above ground. Formerly the approach, in very general terms, was to reduce a structure to the simplest components that could be considered to lead an independent structural existence-joists, girders, columns, walls, slabs; the loading each component could sustain without permanent deformation was then calculated according to simple rules based on tests on such components in isolation ; finally, each component was assumed to be similarly loaded in the complete structure, needing to be strong enough to support the worst probable load distribution. Any component not designed for strength was assumed to make no contribution. Nowadays, the tendency is to consider the behaviour of the complete structure, to measure stresses at critical points in buildings under construction and after completion, to account for these results by more refined theories of stress-strain pattern, and finally to interpret these theories in terms of convenient rules for design. The important thing is that investigation starts with what actually happens in actual structures.

The Building Research Station's work on foundations engineering, since it is carried on chiefly in the field, had to be demonstrated mainly by photographs. Two model-scale investigations were exhibited : in one, a glass-sided tank is used for studying the effect of seepage under hydrostatic pressure at the base of a sheet pile cofferdam; in the other, the effect is examined of proximity between piles in a group on the bearing capacity of each.

Another exhibit included part of the equipment used for measuring pore-water pressures during the construction of earth dams. Pore-water pressure tends to reduce the shear strength of the soil, with a consequent risk of instability as the height of earth fill is increased. Piezometers, incorporating a rigid porous membrane that supports the stresses due to solid material while transmitting hydrostatic pressure, are buried in the dam as work proceeds, permitting direct measurement of pore-water pressures to be made afterwards at a distance. This enables appropriate precautions to be taken if the pore-water pressure threatens to mount too high in relation to the factors contributing to stability.

\section{LAND USE IN BRITAIN}

A CONFERENCE on "Land Use in Britain" was held in the University College of the SouthWest at Exeter during July 15-16. It was organized by the Division for Social and International Relations of Science of the British Association, under the chairmanship of the president of the Division, Mr. P. Ritchie Calder. The Division in this way revived its pre-war function of holding occasional meetings in different parts of the country to discuss problems in which both scientific and social questions are involved. The excellence of the prepared papers and of the discussion, and the success of the conference as a whole, fully justified this initiative.

The theme of the conference was particularly appropriate at a time when most of the local planning authorities in Britain have completed their development plans, as they were charged to do under the Town and Country Planning Act of 1947.

The first speaker was Sir George Pepler, who was chief technical adviser to the Ministry of Town and Country Planning during 1943-46 and planning adviser to the Government of Singapore during 1950-54. His theme was the administrative arrangements necessary to reconcile the demands for land for many different purposes-agriculture, housing, forestry, recreation, military training, roads, airfields, etc. Sir George emphasized that at present the framing of a national policy of land use is greatly hampered by the number of government departments involved--just as at local government level planning is hampered by the number of local committees. He urged that there should be more co-operation at both central and local government levels. As soon as possible the Minister should summarize statistically the information contained in the first batch of development plans; the summaries should be reviewed and brought up to date every five years, thus producing a periodic 'balance sheet' of the land use of Great Britain.

Mr. Geoffery Clark, planning officer for Devon, then described some of the planning problems of local authorities from his own experience. Above all, he said, it was important to "take the public with you". Plans should not be imposed from above. He had found scale-models particularly helpful in explaining planning schemes to the public.

The second session of the conference considered the need of land for agriculture and forestry. Prof. L. Dudley Stamp, professor of social geography in the University of London, discussing competing uses for land, said that while in the United States there are about thirteen acres of land, including 4-5 acres of productive land, per head of population, in Great Britain there is about 0.8 acre per head, which includes about half an acre of productive farmland. The full use of our present farmland could support a little over half our population. Some 35,000 acres a year of agricultural land would probably be needed for housing, industry and other purposes during the next twenty or so years. Industry must have first priority in an industrial nation, especially as its choice of site was often determined by natural factors such as the location of mineral workings. Housing came next, and here there was considerable controversy as to desirable housing densities. It should not be forgotten that only about a fifth of the agricultural land taken for housing remained potentially productive. Further, the quality of land used should be taken into consideration. If an acre of average 
land represented one 'potential production unit', then an acre of poor land would represent $0 \cdot 1$ unit, while one of good land would represent two units. The value of a piece of land lost to agriculture could thus vary by a factor of 20 . It was therefore most important to ensure that the right land was used for the right purpose.

Sir James Turner, president of the National Farmers Union, then enlarged upon the importance of agriculture to the country. It was an unfortunate fact that the best farmland was very often also the most suitable for other purposes. Farming represented one-twentieth of the national income, and its output was now 153 per cent of the pre-war average, although the total labour force had decreased. Pursuing the question of the productivity of back gardens, Sir James said that while it might be true to say that garden produce was worth $£ 66$ per acre while farm produce was only worth $£ 45$ per acre, one must not lose sight of the fact that building houses moant building roads, schools, factories and shops as well. If this were taken into account, the value of garden produce averaged over the whole built-up area was about $£ 20$ per acre. What is more, gardens were not really replacing agricultural produce, and the proper comparison to make was with horticultural holdings, which produced about $£ 350$ per acre. The land was our only irreplaceable national asset, and once built upon was lost for ever. A coherent national policy for land use which bore this in mind was urgently required.

In the discussion, Mr. F. J. Osborne, chairman of the Town and Country Planning Association, said that increasing housing densities would not save much agricultural land. If we were to build three million houses, at fifteen houses per acre, over the next twenty years, this would use about half a million acres, or 1-1 $\frac{1}{2}$ per cent of the remaining agricultural land of Great Britain. Increasing this density to eighteen houses per acre would not save more than 25,000 acres. To save one acre of land by building flats would cost about $£ 20,000$ in additional building costs.

The third session of the conference considered three special aspects of land use. Mr. Langley Taylor, deputy chairman of the Council for the Preservation of Rural England, said that the Cinderella of planning was amenity-not appreciated until lost; since it cannot be valued in money, it was too seldom taken into consideration. The National Parks were a step forward of great importance. Good management of forests and farmland was essential to the amenity value of the land, and here efficiency was more valuable than sentiment. We still had a long way to go before our development enhanced and did not destroy the beauty of the land.

Major L. E. Andrews from the War Office discussed the Army's needs for land for training purposes. National Service, with its greater turnover in men, modern weapons with their greater firing and manceuvring area, and modern battle training techniques had all increased the amount of land needed. About 600,000 acres of land was required for Army training; but only about 8 per cent of this land would be lost to agriculture. The Army was not in a position simply to grab land, as reports in the Press sometimes seemed to imply. The planning and agricultural authorities were always consulted, under an agreed procedure, as was the Council for the Preservation of Rural England. Usually agreement was reached; but if it was not, a public local inquiry was held, which the Army could, and sometimes did, lose.

Prof. S. H. Beaver, University College of North Staffordshire, discussed the need of land for mineral exploitation. Some 5,500 acres a year were used for this purpose at present, but by no means all of it was permanently lost to agriculture, and some of it could also be built on afterwards. Lower-value minerals like chalk, clay and gravel, which were widespread in occurrence, had to be mined where demand and transport costs made it most economic. There had been much progress recently in land reclamation methods, which meant that the sites of many old mineral workings could be built on, afforested or returned to agriculture.

During the fourth session, three papers were read to the conference on the need of land for urban and industrial development. Sir Herbert Manzoni, chairman of the Building Research Board (Department of Scientific and Industrial Research), said that production lines and mechanical handling had tended to increase the amount of space required by industry, and the majority of new factories were single-story. This trend might be reversed by developing vertical production lines and building upwards. Numerically, the population of Britain was very nearly housed, although housing is unevenly distributed; nevertheless, we already had nearly one house to three people. The real problem was the dreadful congestion of some of the urban areas. We were tending to forget the art of urban living, and in solving congestion problems we should not forget that some people like to live in towns. Current development plans would probably moan that a further half a million acres would be needed for urban development in addition to the two million acres at present occupied by housing, schools and industry. This was quite a small proportion of the total amount of land available.

Mr. P. A. Macrory, chairman of the Location of Industry Committee of the Federation of British Industries, produced three criticisms of the impact of land planning over the past three years. First, it was often far too difficult to find out exactly what the planning policy for any particular area was. Secondly, an industrialist who learns that he will be ' $n$ on-conforming' in five, ten or twenty years time often cannot discover when he will have to move, nor how much compensation he can expect. Lastly, planning control was carried down to quite unnecessary detail, and there tended to be a general negative attitude towards the industrial developer. These points all tended to get planning a bad name, but they could be remedied by more consultation and a more constructive attitude.

Prof. J. Sykes, of University College, Exeter, examined the effect planning has had on the location of industries in the past ten years. It appeared that it had so far been fairly successful in combating industrial congastion. One loophole was the fact that industrial premises vacated by non-conforming firms would be immodiately filled by new firms. The local authority should supervise the change of use of premises and have the duty to offer alternatives to firms.

Summing up the conference as a whole, the chairman emphasized that this subject must be seen in relation to national and international economy. The increase in world population, and the industrialization of food-exporting countries, meant that if we wanted to import food we should only be able to do it by producing goods at a very high level of scientific and 
industrial achievement. In deciding the best way to divide the very limited amount of land available so that it was used to the best advantage for the whole of Britain, it was essential to know exactly what one had to divide.

This brought the conference back to the point made by Sir George Pepler at the beginning of the conference, and which came up repeatedly in discussion, namely, the need for more accurate information about how land is actually being used in Great Britain-for, as Dr. Wibberly, of Wye College, pointed out at one point, even the figures of urban acreage are in dispute.

The conference therefore concluded by agreeing to forward the following resolution to the Council of the British Association: "That the British Association for the Advancement of Science represent to Her Majesty's Government the importance of arranging for the collection and publication of comprehensive statistics of the present use of all land in this country and to prepare an analysis on a national basis of the development plans now being submitted for approval in such a way that a balance sheet of land use may be drawn up. The Association submits that the collection of this factual information is a vital need in the present stage which town and country planning has reached in this country and in the formulation of national policies of land use". JoHN Davy

\section{SOCIETY FOR THE STUDY OF FERTILITY}

\section{ANNUAL CONFERENCE}

$\mathrm{T}$ HE Society for the Study of Fertility held its annual conference during June 23-24 in the Anatomy Department of the University of Birmingham. Prof. A. M. Daleq discussed some of the processes of synthesis occurring during the early stages of embryological development in rodents, as revealed by cytochemical studies. In the first of two stages which can be differentiated, there is a step-wise production of deoxyribonucleic acid. In the second stage, heralded by the differentiation of the embryonic knot, synthesis leads to the formation of granules rich in ribonucleic acid, which afterwards gives rise to specific proteins and the formation of enzymes. The enzymes at first are polyvalent; but later different specific enzymes appear. Embryonic development will be described more and more in terms of biochemical differentiation; at present, of course, it is possible to demonstrate this only in terms of cytochemistry. R. A. Beatty described experiments with rabbits designed to test the Russian hypotheses that heterospermic insemination (where semen from two or more donors is mixed prior to insemination) leads to specially beneficial effects among the offspring in respect of litter size and foetal weight. The results he has obtained give no support whatever to these views, and it is concluded that the litters derived from heterospermic insemination are in no way superior to those resulting from homospermic insemination.

W. R. M. Morton has studied the effects on the mating behaviour of rats eaused by section of the olfactory tracts and removal of the olfactory bulbs. He concludes that complete removal of the olfactory pathways interferes with the total mating reaction but does not entirely prevent effective copulation.
P. P. Scott and M. A. Lloyd-Jacob have made a study of reproduction in the domestic cat as maintained in an animal colony. It proved possible to follow the cestrous cycle by means of vaginal smears, and cestrus was found to occur at 12-14 days intervals, lasting 4-6 days. Typical estrous behaviour was usually shown only in the presence of a tom cat, and the authors described a characteristic lateral flexion of the tail which was never observed except when œstrogens were present in significant amounts. Several consecutive matings during the period of œstrus seemed to be necessary in order to lead to conception, and the average duration of pregnancy was 65 days. A remarkable excess of males over females in the litters born was found, the ratio being 133 males per 100 females at birth.

Further studies were reported from the Anatomy Department of the University of Liverpool, under the direction of Prof. R. G. Harrison, on male reproductive physiology. E. W. MacMillan and R. G. Harrison demonstrated that the ductus epididymidis possesses an inherent peristaltic activity essential to sperm propulsion by following radiographically the passage of 50 per cent barium sulphate solution injected into the rete testis. Within four days of injection, the mass occupies a position at the junction of body and tail, and by seven days it has reached the tail loop. The vas deferens is entered on the thirteenth day, and the genital tract is completely emptied by the fourteenth day. The rate of progress is unaffected by ligation of the vasa efferentia or by ipsilateral orchidectomy. R. Harris and R. G. Harrison have investigated the effeet of low temperature on the guinea pig testis. They found that little permanent damage resulted, provided the temperature within the testis did not fall below $0^{\circ} \mathrm{C}$., and that freezing was more damaging than supercooling. Below that temperature occlusive spasm of the testicular artery occurred. Severe spermatogenic damage resulted from exposure of the testis to $-3^{\circ} \mathrm{C}$. for one hour, but a temperature of $-10^{\circ} \mathrm{C}$. was necessary to ensure an intratesticular temperature of $-4^{\circ} \mathrm{C}$. when the scrotum was frozen. Severe spermatogenic destruction led to a 90 per cent fall in testicular volume.

T. D. Glover described the effects of scrotal insulation, as a means of raising the testicular temperature, on the semen of the ram. Five days elapsed before any changes in the semen appeared, and then an increased proportion of coiled tails was seen. Following this, separation of heads and tails was observed, and a marked fall in the sperm density took place about two weeks after the commencement of the scrotal insulation. Insulation for a period of only twenty-four hours led to a brief change in the semen about twenty days later, but, after a further four days, the normal semen picture was resumed.

M. W. H. Bishop discussed the inter-relationships of semen characteristics in the bull. Conception-rate was found to be most closely correlated with impedance change frequency and inversely with the percentage of dead sperms. The most significant conclusion, however, arising from his study was that a large amount of variation in fertility could not be related to any of the numerous semen characteristics examined. E. G. Bassett gave a review of investi. gations recently carried out at the Ruakura Animal Research Station in New Zealand on problems related to fertility in farm animals.

A number of papers on human fertility were given by workers at the Royal Free Hospital, London. 